\title{
The Effectiveness of Training Defense Model for U-13 Players
}

\author{
Ardo Okilanda*, Firmansyah Dlis, Hidayat Humaid, Widiastuti, Dede Dwiansyah \\ Putra and Desy Tya Maya Ningrum
}

\author{
Postgraduate Program, Jakarta State University, Jakarta, Indonesia \\ *Corresponding author. Email: ardookilanda_por16s3@mahasiswa.unj.ac.id
}

\begin{abstract}
Defense training model generally implemented in football player since 13 years old. Defense training model phase applied tactic. This paper aims at the effectiveness of coaching defense toward football players in defense strategy U-13. The sample in this paper consisted of 60 samples of U-13 players. This paper was conducted for two months, with eight exercises and fifty defense training models with defense training materials: warm-up, individual, group, and team. The method used a quantitative quasi-experimental t-test with pre-test and post-test. The results showed differences in the effect of the defense training model on the U-13 football game with a significance $\mathrm{t}$-count $=-17.820 \mathrm{db}=59, \mathrm{v}$ value $=$ $0.00<0.05$. There was a significant difference before and after treatment. Implementation in the training model needs to emphasize the reward points of the defending players in training because it gives more motivation when the defender can do their job and is rewarded in the form of training points.
\end{abstract}

\section{Keywords: Defense model, U-13 player, Football game.}

\section{INTRODUCTION}

Football, in particular, is the sport with the most popular serving around the world. The sport that dominates everyday life [1], football has become an industry worldwide. This 11 vs. 11 game is in the news every day because many dramas happen in it. Even football players are more famous than the heads of the country because they give everyone a lot of inspiration, especially on the health side. Football players maintain their health [2]. The phase of playing football has an attack and defense phase. The fundamental focus of this paper is the defensive phase of football. There are many deficiencies in the observational record of the defense carried out in every U-13 football match.

Between 12 and 17 years of age, a football player/child can experience maximum physical and motor development. When they become adults, players can be given more portion of defensive training [3]. Junior football players are difficult to control their emotions, so they tend to impose their will in practice to force themselves in making movement decisions and combinations of basic football techniques [4]. The consideration of the player's age is very important in papering the form of football game tactics because it is related to accepting the response obtained to the stimulus given in each exercise [5].

Sports are influenced by several factors: physical, technical, tactical, and mental [6]. In the early stages of development, players are trained in the technique. The football technique movement technique has 8 movements: 1 . carrying the ball, 2 . kicking the ball, 3 , stopping the ball, 4, heading the ball, 5. Deception, 6 . Grabbing the ball/tackling, 7, throwing the ball, 8 . Catching ball/goalkeeper [7]. Seizing the ball is implementing the defensive phase in securing the ball, mostly done by taking the ball from the opponent. To play good football, an important thing is needed, namely the mastery of basic football techniques [8].

Team sports are dynamic with various challenges that are more complex with a complete system studied [9]. Football has currently required the mastery of players in various positions. In the past, the defender only served as a barrier for attackers to score goals. [10] Nowadays, defenders also provide forward support to score goals. On the other hand, attacking players help the defense in an attempt to thwart the goals. Team sports a complex sport due to circumstances that can quickly change the position or strategy played [11]. Today, football players must be able to master at least two positions in defense or attack to play an active role in the game system.

Training is a form of system arrangement aiming to improve performance both individually and in football teams [12]. Basic training in technical completion continued with improvement carried out on U-13 players in the defensive phase into the tactical category, which greatly influences the player's career in the future to develop the game, because the player has chosen the position he wants in the game of football. The defensive model process must consider the opponent and the situation with a complete system [13]. The player must know when dealing with an opponent in the match 
situation at hand for the movement to be carried out correctly. Players must already have advanced insight into the play patterns dynamically, both attack and defense [14]. Tactics are carried out with various forms of variation. They are made with their players' innovations to make it difficult for the opponent to read and give winning contributions.

The role of tactics is $46 \%$ under the player's ability so that it is quite influential on the success of a team in winning [15]. Tactic battles always occur in every match, so the coach needs to apply the training model patterns in his training sessions. The delay in learning tactics is also the source of the defeats that occur in the match. Football players at U-13 are a fundamental skill phase that is reproduced in training. Still, at the age of 13, the players have started to get training to apply game patterns, so that here is the initial age to learn defensive training models/football tactics.

The defensive position in football is easy to remember if the defensive position area is at the back end of the corner, forming the letter $\mathrm{V}$ [16] from the midfield line area as shown in picture 1 .

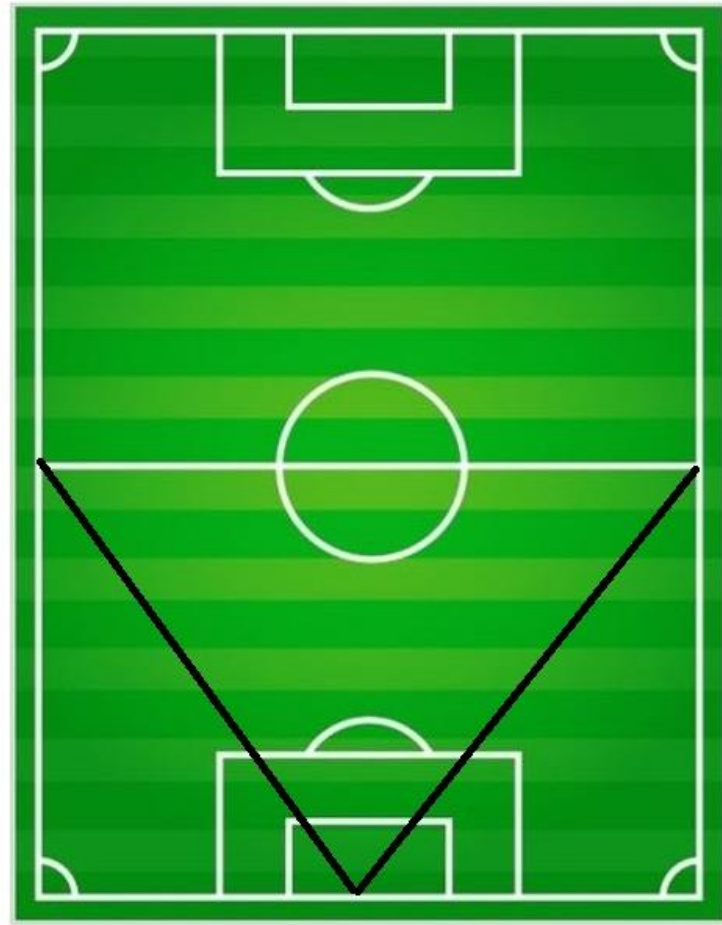

Picture 1. Defensive Position

In defense, the defender must know the dangerous area when closing the goal area so that no goals occur. The ball outside or below zone V is declared a safe area from attacks on goal. Players can perform a combination of defensive tactics in this defensive position [17]. Defenders also work together individually on defensive tactics, then the defensive group consists of 2 or 3 people, and finally, the defending team is four or more. The key to defense is where the player is closer to the ball, which is the first forward chasing the ball to get the ball away from the opponent [18].

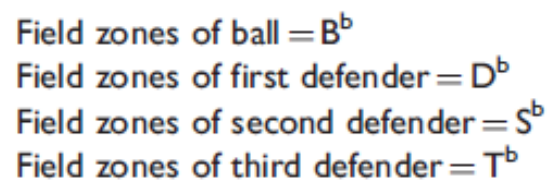

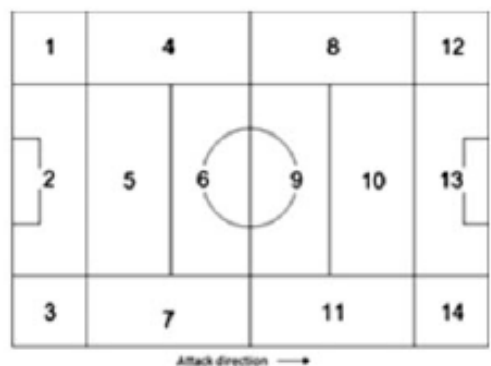

\section{Criterion 14: End of defensive phase}

\section{Picture 2. Defense Zone}

1. Zone 1 left ultra defense is the most important last defense from the left.

2. Zone 2 center ultra defense is the last defense from the middle side in this zone that has scored the most goals.

3. Zone 3 right ultra defense is the last defense that is most important from the right.

4. Zone 4 left sector defensive and midfielder, the defensive team's first defense assisted by midfielders.

5. Zone 5 is the central strip and defensive sector, which is the most dangerous area of defense where attacking players have made many innovations in this zone, whether it is a kick directly at the goal or a pass that goes into zone 1 .

6. The zone 6 central strips defensive midfielder is the midfield's initial defense zone that must be closed first assisted by attackers and midfielders.

7. Zone 7 right sector defensive and midfielder is the starting zone of defense with midfielders' cooperation as the initial defense.

The awareness toward seven defensive zones is important to be recognized by the players first because it determines the player's attitude in a certain position to complete the task.

\subsection{Related Work}

Divide the paper into the smallest and simpler parts to paper by limiting the scope [19]. The previous paper, "The Effectiveness of Drill Strategies to Survive 
Football Strategies Under 21" was explained from the paper's results on the development of the U-21 soccer defense drill training model [20]. The paper results concluded that in simple terms, drill defensive football training is very effective in improving U-21 football players' defensive ability because the focus is on the individual skills of the defender. The results of the paper with the title "tactical awareness, decision making and attacking skills in youth soccer players (under-16 years)" describe the importance of tactics in playing football so that it can influence decisions and skill application [15]. Football defensive tactics have a special portion that must be repeated in training, so the importance of having a regular program training guide is the key to a successful defense.

\section{Manual interactive assumption generation}

This paper focuses on playing the role of players in defending, regarding the player's responsibility when defending and the player as a whole to help defense with tactics as a team, group, and individually. Players do not feel that their role in maintaining defense is an achievement. Players only judge the goal scorer as an achievement.

\subsection{Our Contribution}

This paper provides a note of improvement in an exercise starting from warming up before specific training to defensive training continued to individual training in defense, group, and team defense. The previous training model is not complete with a structured training system in one exercise.

\subsection{Paper Structure}

This paper is divided into four parts, namely 1 . Introduction, 2. Methods, 3. Results, and 4. Conclusions.

\section{METHODS}

This paper used a quasi-experimental method. Pretest and post-test design control group. That is done to investigate causal hypotheses about causes that can be manipulated by comparing one or more experimental groups that are treated with one comparison group that is not treated [21]. This study's design is applied because it follows the study's objectives, where the aim is to find out whether there is a difference between the practice of basic effective soccer tactics and other tactics to improve defense football players. This research uses descriptive statistics in the form of mean, min, max, and standard deviation and uses inferential statistics. The inferential statistics used are independent sample t-tests. Research on the development of this model represents the final results of the U-13 year defense training model with dissemination in articles and books. This study produced a product in the form of a defensive exercise, specifically testing its effectiveness.

Sampling of pre-test and post-test data with defensive instruments that have been validated by AFC licensed A football experts and football lecturers of measurement tests and soccer training model experts. The instrument testing results obtained the validity and reliability of $0.97>t$ table 0.66 Guilford's interpretation was reliable. The assessment was based on correct defensive tactics, one-on-one guarding, tackling, zoning, and cooperation.

The subjects of the study were 120 U-13 players. Sixty experimental groups and 60 control groups. The experimental group with the effectiveness of the defensive training model and the control group with conventional training. Group A, the experimental group, and group B, the control group [22].

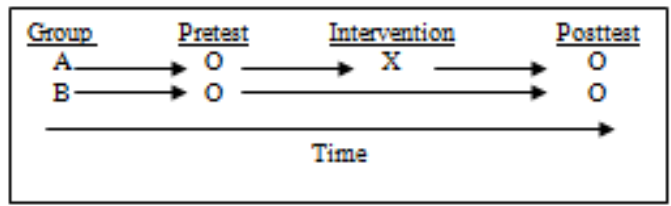

Picture 3. Methods Group

Based on the picture, both groups $\mathrm{A}$ and $\mathrm{B}$ performed a preliminary test. Group A, the experimental group was given the treatment of the defense training model in training. For the conventional training applied control group. Finally, the final test was carried out to see the difference in the experimental group's training results with defensive training and the control group with conventional training.

\section{RESULTS}

The defense model design was verified by 50 defense models with experts in B license football and test and measurement lecturers and football school coaches.

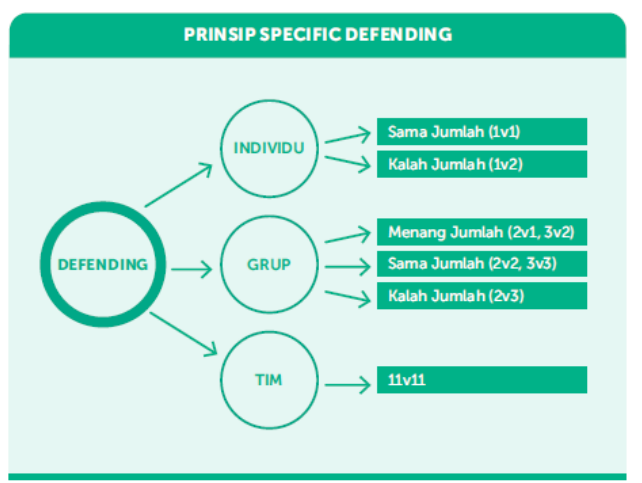

Picture 4. Defending Principle 
Based on the results of field analysis with observations made through interviews, questionnaires, and videos. Arranged based on specific principles of defense [23], the defensive position of the players individually paying attention to the opponent's movements with the ball and without the ball [23] the group's defense moves to zone pressing and the team's defense moves together to support the defense.

The initial test was carried out by testing the normality of the sample with the Kolmogorov Smirnov value for the pre-test model data for the U-13 (X1) soccer player defense training model of 0.176 with Asymp. Sig. (2-tailed) $=0.000>0.005$, meaning that the defense training model is normally distributed.
Meanwhile, the value of the Kolmogrovsmirnov posttest data for the U-13 football (X2) training model for defense is 0.153 with Asymp. Sig. (2-tailed) = 0.016> 0.05 , which means that the defense training model is normally distributed. After seeing the results of the normality test, the data was declared normal.

The homogeneity test of the summary table 2 results shows that $\mathrm{Sig}=0.074$ is greater than the $5 \%$ significance level; this is indicated by Sig> 0.05 . Because Sig $=0.074>0.05 \mathrm{tt}$ can be concluded, there is no difference between the variance of the pre-test and post-test data on the defense training model of U-13 football players, which means the data is homogeneous. It is carried out as a requirement for t-test data analysis.

Table 1. Normality test

\begin{tabular}{|c|c|c|c|}
\hline & Pre & Post \\
\hline \multicolumn{2}{|l|}{$\mathrm{N}$} & 60 & 60 \\
\hline \multirow{2}{*}{ Normal Parameters ${ }^{\mathrm{a}, \mathrm{b}}$} & Mean & 19,80 & 14,55 \\
\hline & Std. Deviation & 1,754 & 1,721 \\
\hline \multirow{3}{*}{ Most Extreme Differences } & Absolute & , 176 & 153 \\
\hline & Positive & ,176 & 130 \\
\hline & Negative &,- 095 &,- 153 \\
\hline \multicolumn{2}{|l|}{ Kolmogorov-Smirnov Z } & ,176 &, 153 \\
\hline \multicolumn{2}{|l|}{ Asymp. Sig. (2-tailed) } & ,000 & ,016 \\
\hline
\end{tabular}

Table 2. Homogenity test

\begin{tabular}{|c|c|c|c|}
\hline Levene Statistik & df1 & df2 & Sig \\
\hline 3,243 & 1 & 118 & 0,074 \\
\hline
\end{tabular}

Table 3. Gap Score of defense model football U-13 and conventional training

\begin{tabular}{|c|c|c|c|c|}
\hline Group & Max & Min & Mean & SD \\
\hline Experiment & 24 & 16 & 19.80 & 1.754 \\
\hline Control & 18 & 11 & 14.55 & 1.721 \\
\hline
\end{tabular}

Table 4. T-test result

\begin{tabular}{|c|c|c|c|c|c|c|c|c|}
\hline & \multicolumn{4}{|c|}{ Paired differences } & & \multirow{3}{*}{$\mathbf{t}$} & \multirow{3}{*}{ df } & \multirow{3}{*}{$\begin{array}{l}\text { Sig(2- } \\
\text { tailed) }\end{array}$} \\
\hline & \multirow[t]{2}{*}{ Mean } & \multirow[t]{2}{*}{ Std.Deviation } & \multirow[t]{2}{*}{$\begin{array}{l}\text { Std Error } \\
\text { Mean }\end{array}$} & \multicolumn{2}{|c|}{$\begin{array}{c}\text { 95\% Confidence } \\
\text { Internal of Difference }\end{array}$} & & & \\
\hline & & & & Lower & Upper & & & \\
\hline $\begin{array}{c}\text { Efectivenes Training } \\
\text { Defense Model }\end{array}$ & 5,250 & 2,282 & ,295 & 4,660 & 5,840 & 17,280 & 59 &, 000 \\
\hline
\end{tabular}

The result showed that data obtained by the experimental group's value with the defense training model are more effective than the conventional group. It means that a structured defense training program will be able to improve your defensive tactics. The trainer can modify the given training rules by paying more attention to the training based on effective training. The modified rules must give high spirits for the defender to defend the zone. Based on the table, it is explained that conventional training can improve defensive ability with a value of 14.55. With the defense training model, the increase is better to 19.80 so that application can be carried out in this age group.

\section{CONCLUSION}

Based on data analysis tests and expert tests carried out on 60 people in the experimental group and 60 people in the control group. The final model of football defense training 
for U-13 athletes was obtained. A total of 50 training models are prepared based on training procedures with special defense warm-ups, individual defense training, defense group training, and defense team training. The resulting product is in the form of a book that provides systematic and structured instructions. In the structured training program, it fosters the confidence value of a player to contribute to the defense by being responsible for all players when attacked by the opposing team.

The training model applied significantly increased with the difference in the $t_{-}$count $=-17.280$ or $\mathrm{p}$-value Sig. (2tailed) $0.000<0.05$ and effective for increasing the defensive ability of U-13-year-old football players. This means that regularly repeated exercises performed on players are suitable for implementation.

During training, no player position is differentiated between players positioned as defenders, center, and attackers. But together, they become a defender and attacker to provide knowledge in defense and ability to defend in each position. In training, defender players are given higher scores so that each match also feels that when they succeed in blocking or thwarting an opponent's attack, the player feels happy and happy with a job well done.

Testing with more samples allows for further proving how effective the training model can be with national or international players with the limitations of the research team only covering provincial areas.

\section{ACKNOWLEDGMENT}

This Work was supported by PGRI Palembang University, Jakarta State University, Sport Science Faculty (7217168229).

\section{REFERENCES}

[1] A. Okilanda, F. Dlis, H. Humaid, and D. D. Putra, "Perbedaan Pengaruh Metode Latihan dan Motivasi Berlatih Terhadap Teknik Dasar Sepakbola Sekolah Sepakbola Beji Timur U-13," J. Educ. FKIP UNMA, vol. 6, no. 1, pp. 80-89, 2020.

[2] T. Hughes, J. C. Sergeant, D. A. van der Windt, R. Riley, and M. J. Callaghan, "Periodic health examination and injury prediction in professional football (Soccer): theoretically, the prognosis is good," Sports Med., vol. 48, no. 11, pp. 24432448, 2018

[3] S. Sulistiyono, "Development and Validation of Kid Tsu Chu Futbol Games for Character Development," J. Phys. Educ. Health Sport, vol. 4, no. 1, pp. 29-34, 2017.

[4] C. J. Carling, "Physical performance in professional soccer match-play: factors are affecting, characteristics and consequences for training and preparation," Ph.D. Thesis, University of Central Lancashire, 2012.

[5] P. H. Y. Kiram, Belajar Keterampilan Motorik. Prenada Media, 2019.
[6] M. Ridhowi, "Football Holistic," Jakarta : Aswara Jaya, 2016.

[7] G. Curry, "The making of modern soccer: a product of multiple interdependencies," Soccer Soc., vol. 20, no. 7-8, pp. 1014-1024, 2019.

[8] A. Okilanda, "Analisis Pembelajaran Gerak Keterampilan Teknik Dribbling Ssb Imam Bonjol Padang," Wahana Didakt. J. Ilmu Kependidikan, vol. 15, no. 3, 2017.

[9] T. Reilly, J. Cabri, and D. Araújo, "Applications of Dynamical Systems Theory to Football," in Science and Football V, Routledge, 2005, pp. 570-572.

[10] Z. P. Daryanto, "Pengembangan model latihan strategi serangan dalam permainan futsal (Studi pada Pemain Futsal Putra Tingkat Intermediate di Kota Pontianak)," PhD Thesis, UNS (Sebelas Maret University), 2013.

[11] T. McGarry, D. I. Anderson, S. A. Wallace, M. D. Hughes, and I. M. Franks, "Sport competition as a dynamical self-organizing system," J. Sports Sci., vol. 20, no. 10, pp. 771-781, 2002.

[12] D. Sukadiyanto \& Muluk, "Pengantar teori dan metodologi melatih fisik," Bdg. Lubuk Agung, 2011.

[13] J.-F. Grehaigne, D. Bouthier, and B. David, "Dynamic-system analysis of opponent relationships in collective actions in soccer," $J$. Sports Sci., vol. 15, no. 2, pp. 137-149, 1997.

[14] J.-F. Gréhaigne and P. Godbout, "Dynamic systems theory and team sport coaching," Quest, vol. 66 , no. 1, pp. 96-116, 2014.

[15] S. González Víllora, L. M. García López, D. Gutiérrez-Díaz, and J. C. Pastor-Vicedo, "Tactical awareness, decision making and skill in youth soccer players (under-14 years)," 2013.

[16] J. Bangsbo, B. Peitersen, and J. Bangsbo, Defensive soccer tactics. Human Kinetics Champaign, IL, 2002.

[17] J. Bangsbo and B. Peitersen, Soccer systems and strategies. Human Kinetics, 2000.

[18] T. Fernandes, O. Camerino, J. Garganta, R. Pereira, and D. Barreira, "Design and validation of an observational instrument for defence in soccer based on the Dynamical Systems Theory," Int. J. Sports Sci. Coach., vol. 14, no. 2, pp. 138-152, 2019.

[19] R. Duarte et al., "The ecological dynamics of 1v1 sub-systems in association football," Motricidade, vol. 5, no. 3, p. 49, 2009

[20] K. Jarrett, "The Effectiveness of Drill Strategies to Survive Football Strategies Under 21," Asian J. Sports Sci., vol. 8, no. 1, pp. 1-17.

[21] D. T. Campbell and J. C. Stanley, Experimental and quasi-experimental designs for research. Ravenio Books, 2015.

[22] M. E. Winarno, "Research Methodology in Physical Education," Malang Fac. Educ. Malang State Univ., 2007.

[23] H. P. U. PSSI, Kurikulum Pembinaan Sepakbola Indonesia. Jakarta: PSSI, 2017. 